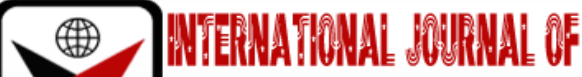

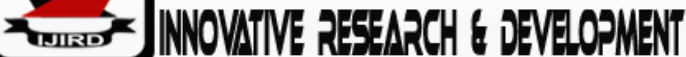

ISSN 2278-0211 (Online)

\section{Employee Engagement, Organizational Intimacy and Talent Management: A Common Buzz Phrase in the Human Resource Development}

Dr. Anazodo Rosemary
Senior Lecturer, Department of Public Administration
NnamdiAzikiwe University, Awka, Anambra State, Nigeria
Ezenwegbu Nchedochukwu Chinwendu
Academic Researcher, Department of Public Administration,
NnamdiAzikiwe University, Awka, Anambra State, Nigeria
Dr. Chukwurah D.C.J
Professor, Department of Public Administration
OdimegwuOjukwu, University Igbariam, Anambra State, Nigeria

\begin{abstract}
:
Major changes have become a part of the business practices for most of the organizations due to tough competition for most of the organizations. This is the ultimate reason behind the frequent demand for the changes. For both organizational behavior and human resource development, concerns have been increasing for employees. This has also become very important for making strategic decisions. It also helps to gain sustainability along with fulfillment of goals. Showing importance to employees also encourages the concept of employee rendezvous, organizational familiarity and talent management. This work aims to find more in-depth concepts of Employee engagement, organizational intimacy and talent management as well as association among them.
\end{abstract}

Keywords: Employee engagement, organizational intimacy, talent management

\section{Introduction}

In the field of Human Resource, some terms like employee engagement, organizational intimacy and talent management have become very popular. The tough competition has made these terms further popular. As per Evans (2014), the importance of employee has become an extreme important phenomenon for making the strategic decisions. These concepts of employee engagement also help up to great extend in the job satisfaction and efficiency of employees. The prime objective is to explore reflective and empirical light over the concept of Employee engagement organizational intimacy and talent management. The concept of these terms is relatively new. Most of the companies have found that giving financial rewards to the employees are not sufficient enough. Providing some of the non-financial rewards affects the employee engagement.

\section{Conceptual Review}

\subsection{Employee Engagement}

There are several other non-financial factors that affects the employee engagement like progression, independence, cultured conduct, manager promise, atmosphere, experience to senior people, admiration, provision, the sensation of being dared and reliable, the feeling of working for a reliable organization and the feeling of respect in worklife balance (Woodruffe, 2016). Most of the companies offer tools for evaluating the drivers that boost the employee rendezvous (Bakker \&Schaufeli, 2018).

The definition of employee engagement is mainly relying on 'activity, initiative and responsibility' (Dvir et al., 2004). The description of behavioural engagement has been highlighted as desire, additional exertion, assurance, the illusive force that stimulates employees to higher levels of performance (Wellins and Concelman, 2015). It also has been highlighted as a strategic process (Kim and Maurborgne, 2015). It also had been explained as how employees perceive their work, leadership (Sanchez, 2017). Cook (2018) highlighted it as desire and liveliness, exerted by the employees. Shaw (2015) called it as intellectual and emotional commitment. Stairs et al (2016) described it as the desire that drives employees for working. Truss et al (2019) called it as a scope for creating opportunities. According to Galpin et al. (2018), it helps to connect colleagues, managers with each other and with the organization. According to Ezegbu, (2016) employee engagement can be described as: 'The degree to which an employee is emotionally bonded to his/her organization and is 
passionate about the work that really matters'. The organization must work to develop and nurture engagement, which requires a two-way relationship between employer and employee. Thus, Employee engagement is a barometer that determines the association of a person within the organization.

\subsection{Real Life Examples of Firms Practicing Employee Engagement}

Many organizations are practicing the concept of employee engagement. Some examples are as follows:

- One promising and growing organization of Nigeria is Ex-G Group. In order to improve the employee engagement, the organization had started practicing the calculation $\mathrm{f}$ bonus based on corporate profits earned by organization.

- Google Inc. for the purpose of making the employees more closely engaged with the organization, had created an informal and creative working environment. Employees can feel like home at the work place and work without any stress (Williams and Windebank, 2012).

\subsection{Organizational Intimacy}

According to Sexton and Sexton (1982) the term 'intimacy' is taken from Latina word Intimus, and it means inner; Intimacy, perception and access to inner personality of people (Povic, 2015). Intimacy is to share inner desires with others or to be seen or see-through sympathy and deep understanding others. Making intimate relations include positive behavioral indicators, that not only it is mental, also it has outer appearance. It means it is a way of relation in which the both sides are experiencing same feelings (Riss et al, 2013).

According to Riis and Shower, (2013) intimacy is an interpersonal process with two main indicators: devotion and responsibility of the other party. Intimacy starts by giving information, thoughts and personal feelings and confessing it from a person to another. Expressing the thoughts and feelings can be either nonverbal or verbal in form of behaviors and devotions (Riis and Shower, 2013).

According to Chinwendu (2016), Most theorists have agreed that intimacy is an emotional state in which people care about and trust one another. In His study on Intimacy and organizational performance, He reviewed the following literatures:

Erikson (1963) purported that intimacy involves a willingness to compromise and sacrifice one's being for the partner's benefit or for the relationship itself, if necessary.

Amidon and Kavanaugh (1981) defined intimacy as a focus on familiarity or closeness with another or others in an organization.

Egan (1970) defined intimacy as an interpersonal experience characterized by self-disclosure and the giving and receiving of feedback.

Prager (1995,) defined it as a 'a positively cathected psychological relationship between two or more people in which partners share that which is private and personal with one another.Chinwendu (2016) summarized by stating that Intimacy involves both intimate interactions and intimate relationships.

Partners in intimate interactions share personal and private information, feel positively about each other and themselves, and perceive a mutual understanding. They share regular intimate interactions, feel affection for one another, trust one another, and enjoy cohesiveness. The concept of cohesion is therefore imbedded within the concept of intimacy, which is dynamic and requires continuing mutual engagement. Trust and self-disclosure are essential to the development of intimate relationships among employer and employees (Horvath \& Van Diest, 2018). In addition, intimacy is a basic human need that involves our innermost selves of people in the organization. Developing private, personal relationships with others is a basic motivator in the organization (Sullivan, 2013). Thus, organizational intimacy is a fundamental component of human nature and a basic ingredient in achieving corporate goals in any organization.

\subsection{Real Life Examples of a Dimension of Organizational Intimacy}

Consider a story from MedAptus, a small Boston medical technology firm. When its marketing director, Jennifer Crowley, faced the tragedy of Cian, her 7-month-old baby's imminent death from a rare pediatric cancer, project manager Andrea BerteBellemare asked Dennis Mitchell, the company's chief executive, for permission to donate three of her leave days to Crowley. Mitchell not only agreed but also went further, creating a staff donation bank. As a result, Crowley received 33 additional leave days from her coworkers which allowed her to keep her job and care for her child. "We felt so helpless," Mitchell reported, "It's really pulled the company closer together to be able to donate time" (Jackson, 2016)

In sum, intimacy is currently viewed as a basic organizational need that is characterized by intimate interactions and intimate relationships. Because it is so basic, we assume that at least some people will seek and value intimacy in their work relationships as they do in their other relationships. Although intimate relationships have been shown to increase interpersonal and self-knowledge in study-group settings, their link with performance outcomes in work relationships such as those in work teams is unclear.

\subsection{Talent Management}

For an organization, talents can be defined as a collection of those who can contribute many things for the organization with their immense potential (Chartered Institution of Personnel Development (CIPD), 2014). The talent of employees can be reflected through services, information, reasoning, intellectual capability and prospective of the employee. Along with these components, values and work preferences are the two most important components (Tansley, Stewart, Turner, Lynette, 2016; Ulrich, 2018). 
The synergic effect of Competence, Commitment and Contribution create talent. Talent can be managed either at individual level or group level. The word “Talent Management” has been coined by McKinsey in the late 1990's. This concept aims to attract and retain employees. It acts as a cohesive factor. It also helps to desirability, retaining, incentive and engagement, development, and succession planning (Armstrong 2016). Chartered Institution of Personnel Development (CIPD) affirms that Talent management is the methodical attraction, identification, development, engagement, retention and deployment of those individuals with high potential (Tansley et al., 2016). Managing talent means building individual and organizational capability that enhances teamwork (Storey, Wright and Ulrich 2019). Lewis and Heckman (2016) revealed that there is 'a disturbing lack of clarity regarding the definition, scope and overall goals of TM' (Tansley, et al. 2016). TM can encompass the whole of HRM (Garrow and Hirsh 2018). In the War for Talent book for instance the authors emphasized identifying the top 10 percent (Pfeffer 2013).

\section{Conclusion}

Organization now aims to give more attention and action to both talent management, employee engagement and organizational intimacy. That attention needs to be well-directed and well-developed. This is summarized by assessing the links between talent management, employee engagement and organizational intimacy.

\subsection{Competitive Advantage}

Competition for talent is violent because talent is a foremost influence in a company's modest benefit. Employing, emerging and retentive talent are the tools that build competitive advantage. Employee engagement adds to developing and retaining talent which in return enhances a level work intimacy in the organization.

\subsection{Performance Improvement}

Talent joins a company appreciating the company and its product. As talent engages more fully in company operations, assignments, projects, that appreciation grows. The greater the appreciation, the greater one's commitment to performing with quality. An employee, especially a 'talent employee' who has the opportunity to perform in ways which she/he sees as valuable consistently seeks to improve that performance.

\subsection{Customer Satisfaction}

Customers naturally prefer to experience quality product and quality service. Research says it is the people with whom customers interact that determine the customer's opinion of that quality. Talent management looks for quality candidates. Employee engagement turns up that quality. Successful attraction and recruitment combine for the first step. Once talent is hired, employee engagement strategies increase communication and commitment or intimacy. These are critical characteristics that satisfy customers.

\subsection{Reduced Turnover, Increased Retention}

If intense effort is made to hire talent, equally intense effort should be expended to retain talent. Employee engagement is a specific element of talent management insofar as it boosts a company's ability to hold on to talented employees. People are intimate and committed with companies they value. The more an employee is allowed and encouraged to engage in job, team, and company efforts, the more she sees the value. People stay and are intimate with managers they trust. The more managers and employees engage in continuous communication about expectation, the more trust develops in their relationship. People stay with companies that offer opportunities for personal, even professional growth. The more your company provides such opportunities; training, mentoring/coaching and community involvement, the more growth the employee witnesses which in return enhances organizational intimacy and or commitment.

\section{References}

i. Armstrong, M. (2016) A Handbook of Human Resource Management Practice. 10th Edition,Kogan Page Publishing, London.

ii. Bakker H.\&Schaufeli, M (2018). Organizations evolving (2nd ed.). Thousand Oaks, CA: Sage Publications.

iii. Chinwendu, E. (2016), The psychology of intimacy. Awka: Re-Opec Publishers.

iv. Chartered Institution of Personnel Development (2014), Reflections on Talent Management,

v. Change Agenda, London: CIPD 2

vi. Cook V. (2018). Second Language Learning and Language Teaching. London:Arnold. ISBN 978-0-340-95876-6.

vii. Dvir, T., D. Eden, B. J. Avolio, \& B. Shamir. (2014). Impact of transformational leadership onfollower development and performance: A field experiment. Academy of Management Journal, 45(4), 735-744. http://dx.doi.org/10.2307/3069307

viii. Evans, H. M. (2014). Competitive intelligence. Financial Management Training Center. Retrievedat January 15, 2016, from http://www.exinfm.com/training/pdfiles/ course12-1.pdf

ix. Evans, H. M. (2014). Competitive intelligence. Financial Management Training Center. Retrievedat January 15, 2016, from http://www.exinfm.com/training/pdfiles/ course12-1.pdf

X. Ezegbu, N.V, (2016) How much should I give and how often? The effects of generosity andfrequency of favor exchange on social status and productivity. Academy of Management Journal, 46, 539-553.

xi. Galpin A., Maname v. \&uwan B. (2018). Social capital at work: Networks and employment at aphone center. American Journal of Sociology, 105(March), 1288-1356. 
xii. GarrowV.and Hirsh W. (2018). The Talent Management Journey, Horsham: Roffey Park Institute.

xiii. Horvath, L., \& Van Diest, R. (2018). Why teams don't perform: The misunderstood concept ofintimacy. Paper presented at the annual meeting of the Academy of Management, California August.

xiv. Jackson, F. (2016). Mentoring at work. Developmental relationships in organizational life.

xv. Lanham, MD: University Press of America.

xvi. Kim Y. and Maurborgne G. (2015). How will market orientation and environment and firm'scharacter influence performance? Cross Cultural Management: An International Journal, 10(4), 71-88. Retrieved at March 15, 2016, from http://dx.doi. org/10.1108/13527600310797702

xvii. Lewis, R. E., \& Heckman, R. J. (2016), “Talent management: A critical review”, HumanResource Management Review, Vol.16, No.2, pp.139.

xviii. Pfeffer, J. (2013). The knowing-doing gap: How smart companies turn knowledge into action. Boston: Harvard Business School Press.

xix. Povic, S.T, (2015). The effects of colleague quality on top performance: The case of securityanalysts. Journal of Organizational Behavior, 29(November), 1123-1144.

xx. Riis and Shower, (2013). The effects of activity-elicited humor and group structure on groupcohesion and affective responses. The American Journal of Occupational Therapy, 41, 510-514.

xxi. Sullivan, N.F (2013). Intimacy. An international survey of the sex lives of people at work.

xxii. Houndmills, Basingstoke, Hampshire: Palgrave Macmillan.

xxiii. Sanchez R. (2017). Introduction: Towards the theory and practice of competence-based competition. Oxford: Elsevier Pergamon. (pp. 1-35).

xxiv. Stairs D., Shaw, S. \&Fairhurst, D. (2016), 'Engaging a new generation of graduates', Education_Training, 50(5), pp. 366-378.

xxv. Shaw, E. H. (2015). The first dialogue on macromarketing. Journal of Macromarketing, 15(1),7-20.

xxvi. Storey, J., Wright, P. M., \& Ulrich, D. (2019). The Routledge companion to strategic humanresource management. London: Routledge.

xxvii. Tansley, C. Turner, P., Foster, C., Harris, L., Sempik, A., Stewart, J. \& Williams. H. (2016). 'Whatdo we mean by the term 'talent' in talent management?' Industrialand Commercial Training, 43:5, 266-274.

xxviii. Tansley C., Stewart J., Turner P, \& Lynette H. (2016), Talent: Strategy, management,measurement, Research into Practice, London: CIPD

xxix. Truss E. Howard, J., \&Cheramie, R (2019). Intimate relationships in task environments. In: S. W.

xxx. Duck (Ed.), Handbook of personal relationships (pp. 449-465). Hoboken, NJ: Wiley.

xxxi. Wellins, R., \&Concelman, J. (2015). 'Creating a culture for engagement', Workforce

xxxii. Performance Solutions (www.WPSmag.com).

xxxiii. Woodruff, R. B. (2016). Customer value: The next source for competitive advantage. Journal of the Academy of Marketing Science, 25(2), 139-153. Retrieved at March 30, 2016, from

http://link.springer.com/article/10.1007\%2FBF02894350

xxxiv. Williams H. and Windebank G. (2012). Emotions in organizational behavior. New York, NY:Lawrence Erlbaum.

xxxv. Ulrich, R. S. (2008, in press). Biophilic theory and research for health design. In S. Kellert, J.

xxxvi. Heerwagen, and M. Mador (Eds.), Biophilic Design: Theory, Science and Practice. New York: John Wiley 